УДК 346.546

DOI https://doi.org/10.32837/yuv.v0i2.2143

\author{
T. Швидка, \\ orcid.org/0000-0002-6152-2705 \\ доктор юридичних наук, доцент, \\ асистент кафедри господарського права \\ Національного юридичного університету імені Ярослава Мудрого, \\ адвокат
}

\title{
ГОСПОДАРСЬКО-ПРАВОВЕ РЕГУЛЮВАННЯ ПОРУШЕНЬ, ПОВ'ЯЗАНИХ ІЗ НЕПРАВОМІРНИМ ВИКОРИСТАННЯМ ДІЛОВОЇ РЕПУТАЦІЇЇ СУБ’ЄКТІВ ГОСПОДАРЮВАННЯ
}

Вступ. Серед правопорушень, передбачених Законом України «Про захист від недобросовісної конкуренції, вагоме місце займає такий вид, як неправомірне використання ділової репутації суб'єкта господарювання, що передбачає вчинення суб'єктом господарювання дій, спрямованих на змішування діяльності недобросовісного конкурента Й суб'єкта господарювання, який володіє відповідною діловою репутацією на ринку. Такі дії негативно впливають як на відповідних учасників ринкових відносин, зокрема споживачів товарів і послуг і виробників таких товарів, так і на ринок в цілому. Серед розповсюджених видів даного правопорушення $€$ підробка, фальсифікація, копіювання зовнішнього вигляду виробу та порівняльна реклама.

Ділова репутація - це важлива складова частина ведення бізнесу, що дає суб'єктивну оцінку, переконання особи щодо бренда, компанії, товарів чи послуг. Це формування у свідомості людини уявлення, про діяльність того чи іншого суб'єкта на ринку. Від ділової репутації залежить ефективність діяльності, привабливість для інвесторів, партнерів, клієнтів і попит на продукцію, що пропонує компанія. Порушення умов використання ділової репутації суб'єкта господарювання $€$ розповсюдженим явищем і має певні недоліки з боку законодавчого регулювання, а отже, потребує модернізації на законодавчому рівні

Аналіз останніх досліджень i публікацій. Дослідженням питань у сфері недобросовісної конкуренції, зокрема ділової репутації суб'єктів господарювання, займалися такі вчені, як О. Бакалінська, С. Волошенко, В. Глухова, В. Пірогова, А. Ридзевська, І. Коваль, О. Сало, Н. Саніахметова, Я. Скабенко, Ю. Слободчикова та інші.

Формулювання цілей. Мета статті - визначити основні види та форми прояву правопорушень, пов'язаних із неправомірним використанням ділової репутації суб'єкта господарювання, проаналізувати їх склад, умови притягнення до відповідальності та практичної реалізації відповідальності за порушення, а також превентивного механізму вчинення даного виду правопорушень.

Виклад основного матеріалу. В умовах сьогодення функціонування компаній на ринках та завоювання своїх позицій відбувається завдяки використанню в господарській діяльності різноманітних матеріальних та нематеріальні активів. Серед нематеріальних активів вагоме місце в діяльності компанії на ринку займає торгова марка, постійна база клієнтів, креативний підхід до управління бізне- 
сом, довіра клієнтів, патенти, інтелектуальний капітал тощо. Усе це формує ділову репутацію суб'єкта господарювання, що збільшує ринкову вартість активів, підвищує інвестиційну привабливість компанії на ринку. 3 огляду на ділову репутацію суб'єкта господарювання можна дати оцінку даному суб'єкту господарювання не тільки з точки зору споживача, але й з точки зору контрагентів. Ділова репутація ототожнюється 3 іміджем компаніï, ii місцем та статусом на ринку. Крім того, ділова репутація впливає і прямо залежить від ефективності діяльності, привабливості для інвесторів, партнерів, клієнтів і попиту на продукцію, що пропонує компанія.

Проте не завжди поняття «ділова репутація» та гудвіл $є$ тотожними. Деякі науковці приходять до висновку, що різниця між «гудвіл» і «діловою репутацією» в тому, що перше є нематеріальним активом і може бути виражене у грошовому еквіваленті, в той час як «ділова репутація» вважається морально-етичною категорією i особистим немайновим благом. А отже, гудвіл можна визначити як вартісний вираз ділової репутації підприємства.

Згідно зі змінами в законодавстві України, а саме в Законі Україні «Про внесення змін до деяких законодавчих актів України щодо спрощення залучення інвестицій та запровадження нових фінансових інструментів» від 19 червня 2020 року було введено поняття ділової репутації, де зазначено, що це сукупність документально підтвердженої інформації про фізичну або юридичну особу, що дає можливість зробити висновок про відповідність ї діяльності вимогам законодавства, діловій практиці та професійній етиці, а також відомості про порядність, професійні та управлінські здібності фізичної особи [1].

Відповідно до Міжнародного стандарту фінансової звітності гудвіл є активом, який відображає майбутні економічні вигоди, що виникають від інших активів, придбаних під час об'єднання бізнесу, які не можна ідентифікувати індивідуально або визнати окремо [2].

Гудвіл являє собою збільшення оцінки бізнесу, зростання його вартості тією мірою, що їй сприяє репутація, авторитет фірми. Тобто це сукупність факторів ділової репутації, вигідності розташування, впізнаваності торгової марки тощо, що дозволяє зробити висновки про майбутнє перевищення прибутковості даної фірми у порівнянні із середньою прибутковістю аналогічних фірм. Виділяють два види гудвіла: створений внутрішньо, що виникає у процесі діяльності компанії та створений зовні, його ще називають набутим, що виникає у процесі злиття та поглинання компаній. Управління гудвілом як невід'ємний елемент формування конкурентоспроможності компаній полягає в будівлі позитивної репутації фірми 3 боку постачальників, покупців, персоналу та суспільства в цілому. Воно існує у вигляді етики у відносинах із зовнішніми та внутрішніми партнерами, ефективності менеджменту, фінансовій стійкості, якості товарів, робіт, послуг, репутації топ-менеджерів, соціальної відповідальності, інноваційності тощо.

Проте дуже розповсюдженим явищем $€$ порушення умов використання ділової репутації суб’єкта господарювання, що є проявом недобросовісної конкуренції і згідно із Законом України «Про захист від недобросовісної конкуренції має такі прояви, як «неправомірне використання позначень», «неправомірне використання товару іншого виробника»; «копіювання зовнішнього вигляду виробу» та «порівняльна реклама» [3].

Якщо суб'єкт господарювання створює продукцію шляхом повного відтворення зовнішнього вигляду виробу іншого суб'єкта господарювання, не зазначаючи при цьому, що це копія, такий вид діяння буде кваліфікуватися як «копіювання зовнішнього вигляду виробу» відповідно до статті 6 Закону України «Про захист 
від недобросовісної конкуренції». Така діяльність суперечить змісту добросовісної ринкової конкуренції.

Виробник, порушуючи законодавство, може у своїй діяльності використовувати однакову упаковку або застосовувати певні знаки, притаманні лише одному суб'єкту господарювання, для того, щоб ввести споживачів в оману, але якість продукції, яку він буде надавати, може суттєво відрізнятися. Відомо, що споживач часто надає перевагу перевіреному бренду, який він уже використовує, розраховуючи при цьому на певний звичний рівень якості даного товару, який, зрозуміло, скопійований надати неспроможний. Отже, купуючи підробку, покупець може назавжди розчаруватися в чесності виробника. Проте на практиці доказу реальної підробки, фальсифікації не завжди вдається за можливе довести реальний факт вчинення правопорушення, а тим більше довести факт реальної шкоди діловій репутації суб'єкта господарювання.

Актуальним на даний момент $€$ з'ясування співвідношення понять «підробка» і «фальсифікація», що вважаються схожими явищами. Передусім вкажемо, що в українській мові вони використовуються як синоніми, а крім того, існує ще й французьке слово contrefaction (контрафакція), що перекладається також як підробка.

Легального визначення терміна «підробка» національне законодавство не містить, у ньому лише міститься трактування поняття «контрафактна продукція», що закріплено в Постанові KMУ «Про затвердження Національного стандарту № 4 «Оцінка майнових прав інтелектуальної власності» від 03.10.2007 року № 1185 [4], згідно з положеннями якої вона тлумачиться як продукцію або примірник, що випускаються, відтворюються, публікуються, розповсюджуються, реалізуються тощо з порушенням майнових прав інтелектуальної власності. Така незаконна діяльність, на думку
В. Пірогової, за всіма своїми відмінними ознаками, звісно, може бути віднесена до недобросовісної конкуренціі: один учасник обігу, незаконним чином привласнюючи результати діяльності свого конкурента, отримує комерційні вигоди [5].

До сказаного слід додати, що між поняттями «підробка (фальсифікація)» i «контрафакція» існують суттєві відмінності, що знаходить прояв передусім у сфері їх застосування. Так, поняття «фальсифікація» використовується в декількох сферах діяльності, у той час як «контрафакція» - тільки щодо порушень, що скоються у сфері інтелектуальної власності. Контрафакція є одним із видів фальсифікації товарів, тому поняття «фальсифікація (підробка)» та «контрафакція» співвідносяться одне 3 одним як частина і ціле.

Підсумовуючи, зауважимо, що розрізняють декілька видів контрафакції за такими критеріями:

1) за формою: А) недобросовісна конкуренція (використання відомої торговельної марки зі зміною деяких ii елементів до ступеня змішування); Б) фальсифікація товарів (розміщення відомої торговельної марки на упаковці й товарі без будь-яких видових змін на підроблених товарах);

2) за способом скоєння: А) введення споживачів в оману; Б) паралельний (сірий імпорт), який прирівнюється до контрабанди.

Найпоширенішим способом реалізації контрафактних товарів є їх збут у мережі Інтернет. Інтернет-магазини забезпечують цілодобовий доступ до товарів і можливість їх придбати на відстані. При цьому ціни на контрафактну продукцію значно нижчі, аніж ціни на оригінальні товари. Названі фактори позитивно впливають на попит на такі товари з боку споживачів. Веб-сайти, розроблені для реалізації контрафактних продуктів, можуть бути не менш якісними, аніж веб-сайти правовласників. Інтернет-торгівля контрафактними това- 
рами може здійснюватися в декількох країнах, що зменшує ризик притягнення правопорушників до відповідальність. Веб-сайт, за допомогою якого здійснювалася торгівля, може бути замінено на новий протягом короткого періоду часу.

Зауважимо, що використання зовнішнього вигляду виробу без укладання відповідних угод заборонене, а таке діяння карається за конкурентним законодавством. Воно може здійснюватися на цілком правомірних засадах, якими може бути, наприклад, колаборація, тобто спільна діяльність кількох компаній для досягнення певних цілей.

Експерти зазначають, що для успішного об'єднання брендів необхідно дотримуватися таких правил:

- бренди, що об’єднуються, мусять мати однакову цільову аудиторію, а умови співпраці мають бути чітко врегульовані між партнерами вже на стадії об'єднання;

- колаборація має носити доповнюючий для партнерів характер, покриваючи слабкі сторони кожного 3 них та забезпечуючи незалежне функціонування на ринку обох суб'єктів господарювання;

- колаборація має бути доступною для споживачів. Сприйняття бренду одного учасника колаборації не мусить негативно відображатися на сприйнятті іншого партнера.

Представники Європейського Союзу висловили думку, що Україні слід прискорити виконання своїх зобов'язань у межах Угоди про асоціацію, особливо у сфері інтелектуальної власності. Так, згідно з умовами «Угоди про поглиблену та всеохоплюючу зону вільної торгівлі між Україною та Європейським Союзом» від 01.01.2016 року, яка є частиною Угоди про асоціацію, передбачено проведення позитивних змін у сфері інтелектуальної власності і забезпечення дотримання законодавства, зокрема, під час перетинання митного кордону.
На окрему увагу заслуговує такий вид неправомірного використання ділової репутації суб'єкта господарювання, як «неправомірне використання товару іншого виробника», що полягає у використанні у своїй господарській діяльності товарів, вироблених іншими виробниками, шляхом приховування цього факту (зняття, приховування та заміна позначень). Метою таких дій недобросовісного конкурента $€$ привернення підвищеної уваги до свого товару за рахунок добре відомих на ринку зовнішніх характеристик товару добросовісного виробника. За своєю суттю таке порушення вважається протилежним копіюванню зовнішнього вигляду товару, оскільки за умови його вчинення позначення суб'єкта господарювання, які мають індивідуалізувати товар такого виробника, змінюються, або не використовуються взагалі.

Проте розслідування таких правопорушень і притягнення до відповідальності правопорушників має певні труднощі 3 точки зору практичного застосування, зокрема, це пов'язано зі складністю виявлення таких порушень та завуальованістю таких дій і подальших перепонах у визначенні початкової приналежності товарів певному виробнику. Більш того, вищезгадана стаття 5 Закону законодавцем викладена не належним чином, отже, іï можна визнати недосконалою, оскільки обмежує об'єктивну сторону такого порушення, використовуючи словосполучення «введенням товару в обіг під своїм позначенням». При цьому поза увагою залишається можливість введення в обіг товару іншого виробника без використання будь-яких позначень у випадку, коли такі товари мали б містити позначення конкретного суб'єкта господарювання.

Керуючись зарубіжним досвідом боротьби $з$ недобросовісною конкуренцією, І.Ф. Коваль наполягає на внесенні змін до закону таким чином, щоб «неправомірним використанням» 
було використання товару іншого виробника як під власним позначенням, так і без нього [6]. Крім того, важливим $є$ доповнення цієї статті різними проявами об'єктивної сторони, що можуть слугувати обставинами, що обтяжують відповідальність. Як-от використання або введення в обіг товарів іншого виробника, якщо ці дії супроводжувалися зняттям чи зміною упаковки, якщо це загрожує товару; порушенням первинного стану товару; використання його не за призначенням; якщо товар випущено під новою упаковкою без зазначення особи, яка переупакувала товар; нова упаковка завдає шкоди діловій репутації виробника товару; виробник не повідомлений про факт переупаковування, йому не наданий зразок нової упаковки.

Дуже важливим і актуальним питанням залишається практичний аспект притягнення до відповідальності правопорушників за прояви недобросовісної конкуренції. Зокрема, це пов'язано зі складністю виявлення таких порушень, що пов'язано із завуальованості таких дій та подальших перепонах у визначенні початкової приналежності товарів певному виробнику. Більш того, вищезгадана стаття 5 Закону законодавцем викладена не належним чином, отже, iii можна визнати недосконалою, оскільки обмежує об'єктивну сторону такого порушення, використовуючи словосполучення «введенням товару в обіг під своїм позначенням». При цьому поза увагою залишається можливість введення в обіг товару іншого виробника без використання будьяких позначень у випадку, коли такі товари мали б містити позначення конкретного суб'єкта господарювання.

Крім того, важливим є доповнення цієї статті різними проявами об'єктивної сторони, що можуть слугувати обставинами, що обтяжують відповідальність. Наприклад, використання або введення в обіг товарів іншого виробника, якщо ці дії супроводжу- валися зняттям чи зміною упаковки, якщо це загрожує товару; порушення первинного стану товару; використання його не за призначенням; якщо товар випущено під новою упаковкою без зазначення особи, яка переупакувала товар; нова упаковка завдає шкоди діловій репутації виробника товару; виробник не повідомлений про факт переупаковування, йому не наданий зразок нової упаковки.

Висновки. Копіювання зовнішнього виду товару, яке $€$ проявом недобросовісної конкуренції, часто має назву «підробка», «фальсифікація», «контрафакція», проте між цими поняттями існують суттєві відмінності, що знаходить прояв передусім у сфері ї застосування. Так, поняття «фальсифікація» використовується в декількох сферах діяльності, в той час як «контрафакція» - тільки щодо порушень, що скоються у сфері інтелектуальної власності. Контрафакція є одним із видів фальсифікації товарів, тому поняття «фальсифікація (підробка)» та «контрафакція» співвідносяться одне 3 одним як частина і ціле.

Використання зовнішнього вигляду виробу без укладання відповідних угод заборонене, а таке діяння карається за конкурентним законодавством. Воно може здійснюватися на цілком правомірних засадах, якими може бути, наприклад, колаборація, тобто спільна діяльність кількох компаній для досягнення певних цілей.

Відповідно до угод, укладених 3 Європейським Союзом, Україна зобов'язалася привести своє законодавство у відповідність до законодавства ЄС. Необхідним згідно із цими зобов'язаннями $€$ реформування законодавства у сфері захисту інтелектуальної власності, захисту патентів та створення компетентних органів, до повноважень яких входить вирішення проблем у галузі захисту інтелектуальної власності, адже порушення у сфері захисту від недобросовісної конкуренції та порушення 


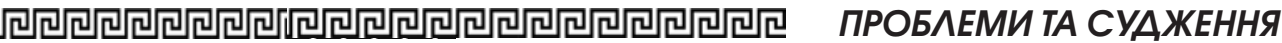

у сфері захисту інтелектуальної власності тісно пов'язані між собою.

Однак за сучасних умов можливість існування права на інтелектуальну власність, що поширюється на винаходи з огляду на поширення в найближчому майбутньому кіборгізаціі, діджиталізації і поглиблення проблем недоторканності особистого життя й спілкування через комп'ютерні мережі, - одне з актуальних питань, що постає перед суспільством.

Неправомірне використання товару іншого виробника за своєю суттю вважається протилежним неправомірному використанню позначень, оскільки за умови його вчинення позначення суб’єкта господарювання, які мають індивідуалізувати товар такого виробника, змінюються, або не використовуються взагалі. Метою таких дій недобросовісного конкурента $€$ привернення підвищеної уваги до свого товару за рахунок добре відомих на ринку зовнішніх характеристик товару добросовісного виробника.

Ділова репутація - цее вид нематеріального актива підприємства, що впливае на його вартісний характер. Серед нематеріальних активів вагоме місие в діяльності компанії на ринку займає торгова марка, постійна база клієнтів, креативний підхід до управління бізнесом, довіра клієнтів, патенти, інтелектуальний капітал тощо. Усе це формуе ділову репутацію суб'єкта господарювання, щио збільшуе ринкову вартість активів, підвищуе інвестиційну привабливість компанї на ринку. Ділова репутація ототожнюеться з іміджем компаніі, ї місцем та статусом на ринку. Завдяки діловій репутаиіï формується суб'єктивна оцінка діяльності того чи іншого суб'екта на ринку, підвищуеться вартість uiєï компанiї.

Серед розповсюджених проявів недобросовісної конкурениіі $\epsilon$ порушення умов використання ділової репутаціï суб'єкта господарювання, що має такі прояви, як «неправомірне використання позначень», «неправомірне використання товару іншого виробника»; «копіювання зовнішнього вигляду виробу» та «порівняльна реклама».

Копіювання зовнішнього виду товару має ще назву «підробка», «фальсифікація», «контрафакція», проте між иими поняттями існують суттеві відмінності, що знаходить прояв передусім у сфері їх застосування. Так, поняття «фальсифікація» використовуеться в декількох сферах діяльності, в той час як «контрафакція» - тільки щодо порушень, що скоються у сфері інтелектуальної власності. Контрафакція є одним із видів фальсифікаціі товарів, тому поняття «фальсифікація (підробка)» та «контрафакція» співвідносяться одне з одним як частина $і$ иіле.

Відповідно до угод, укладених з Европейським Союзом, Україна зобов'язалася привести своє законодавство у відповідність до законодавства ЄС. Необхідним згідно із циими зобов'язаннями є реформування законодавства у сфері захисту інтелектуальної власності, захисту патентів та створення компетентних органів, до повноважень яких входить вирішення проблем у галузі захисту інтелектуальної власності, адне порушення у сфері захисту від недобросовісної конкуренції та порушення у сфері захисту інтелектуальної власності тісно пов'язані між собою.

Неправомірне використання товару іншого виробника за своєю суттю вважається протилежним неправомірному використанню позначень, оскільки за умови його вчинення позначення суб'єкта господарювання, які мають індивідуалізувати товар такого виробника, змінюються або не використовуються взагалі. Метою таких дій недобросовісного конкурента є при- 
вернення підвищеної уваги до свого товару за рахунок добре відомих на ринку зовнішніх характеристик товару добросовісного виробника.

Ключові слова: недобросовісна конкуренція, ділова репутація, підробка, фальсифікація, копіювання зовнішнього вигляду виробу, порівняльна реклама.

Shvydka T. Economic and legal regulation of violations associated with the unlawful use of business reputation and business entities

Goodwill is a type of intangible asset of an enterprise that affects its value. Among intangible assets, an important place in the company's activities on the market is occupied by a trademark, a permanent customer base, a creative approach to business management, customer confidence, patents, intellectual capital, and the like. All this forms the business reputation of the enterprise, which in turn increases the market value of assets, increases the investment attractiveness of the company in the market. Business reputation is identified with the image of the company, its place and status in the market. Thanks to business reputation, on the one hand, a subjective assessment of the activities of a particular entity in the market is formed, and on the other, the value of this company rises.

Among the widespread manifestations of unfair competition is the violation of the conditions for using the business reputation of a business entity, in turn, has such manifestations as "misuse of designations", "misuse of goods from another manufacturer"; "Copying the appearance of the product" and "comparative advertising".

Copying the appearance of a product is also called counterfeiting, falsification, counterfeiting, but there are differences between these concepts, primarily in the field of their application. Thus, the concept of "falsification" is used in several areas of activity, while "counterfeiting" is only about violations that can be found in the field of intellectual property. Counterfeiting is one of the types of falsification of goods, therefore, the concepts of "falsification (counterfeiting)" and "counterfeiting" relate to each other as a part and a whole.

In accordance with agreements concluded with the European Union, Ukraine has undertaken to bring its legislation in line with $E U$ legislation. It is necessary, according to these obligations, it is important to reform the legislation in the field of intellectual property protection, patent protection and the creation of competent authorities, whose powers include solving problems in the field of intellectual property protection, because violations in the field of protection against unfair competition and violations in the field of intellectual property protection are closely related.

The misuse of the goods of another manufacturer is inherently considered the opposite of the misuse of designations, since when it is committed, the designation of a business entity who has to individualize the product of such a manufacturer is changed, or not used at all. The purpose of such actions of an unscrupulous competitor is to attract increased attention to its product due to the well-known external characteristics of the product of a bona fide manufacturer on the market.

Key words: unfair competition, business reputation, forgery, falsification, copying of product appearance, comparative advertising. 


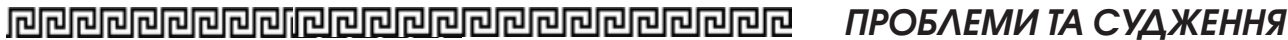

\section{Література}

1. Про внесення змін до деяких законодавчих актів України щодо спрощення залучення інвестицій та запровадження нових фінансових інструментів : Закон України від 19 червня 2020 року № 738-IX. URL : https: / / zakon.rada.gov.ua/laws / show /738-20\#Text.

2. Міжнародний стандарт фінансової звітності. Об’єднання бізнесу. 2012. URL : https: / / zakon.rada.gov.ua/laws / show/929_006\#Text (дата звернення: 24.03.2021)

3. Про захист від недобросовісної конкуренції : Закон України від 7 черв. 1996 р. № 236 / 96-ВР. Відомості Верховної Ради України. 1996. № 36. Ст. 164.

4. Про затвердження Національного стандарту №4 «Оцінка майнових прав інтелектуальної власності»: Постанова Каб. Міністрів України від
03.10.2007 № 1185. URL : http://search. ligazakon.ua/l_doc2.nsf/link1/KP071185.html.

5. Пирогова В. Контрафакт и пиратство: вопросы теории и практики. Ннтеллектуальная собственность. Авторское право и смежные права. 2010. № 12. C. 12-20.

6. Коваль И.Ф. Неправомерное использование знаков для товаров, услуг и недобросовестная конкурениия. Підприємниитвво, господарство і право. 2004. № 4 . C. 7-11.

7. Глухова В.І., Скабенко Я.О. Нематеріальні активи у складі необоротних активів підприємства. Київ : ТОВ «ВІПО», 2020. C. 63-65.

8. Красношапка В.В., Богдан С.C. Ділова репутація як один з найважливіших стратегічних активів підприємства. Сучасні проблеми економіки і підприємниитво. 2012. № 9. С. 210-215. 